\title{
Grammatical and Semantic Word-Formation of Toponymic Derivatives (on the Material of the Toponym "СИБИРЬ")
}

\author{
Anna M. Litovkina \\ Irkutsk State University, Irkutsk, Russia
}

\begin{abstract}
The paper presents morphemic-derivational structure of toponymic derivatives (toponymy-derived formations) of proper name "Сибирь". In revealed derived words authors identify morphemes, specify the methods of their production, provide statistics on word-formation activity of morphemes in the process of secondary nomination of toponymy-derived appellatives. Based on regional material of dialectal dictionaries they define the peculiarities of toponym's wordformation family of words, as well as its paradigmatic relations with derived categories. Horonym "Сибирь" is considered in the context of perception by regional linguistic persona in the national toponymic space. Examples of semantic toponymy-derived word-formation are given. Thereby, in Russian language world picture it is possible to identify a set of regionally marked background knowledge, perceptions of values as well as historical and cultural characteristics of the analyzed toponym.
\end{abstract}

Toponymic language space (toponymic space) is the subject of numerous linguistic studies. Having taken a leading position in the linguistics of the late 20th - early 21 st centuries anthropocentric megaparadigm dramatically expanded the range of issues, problems and challenges in the study of proper names. Modern linguists consider comprehensively word-formation aspect of onomastics, create dictionaries of Russian toponymic derivatives $[1,2]$; they study types and names of regional onomastics systems [3, 4]; investigate associative links of toponyms in the Russian language world picture as well as in the conceptual one [5], compare toponymic space of the past and present [6]; present grammatical as well as lexical and semantic features of toponyms in terms of cognitive linguistics [710], they offer methods within linguistic and cultural studies, contributing to the promotion of the Russian language in the Eurasian area due to modern technologies of teaching the Russian language through the culture and way of life of the peoples of Russia, including Russian Siberia still to be fully explored [11].

This paper presents morphemic-derivational analysis of toponymic derivatives (toponymy-derived formations) of proper name (PN) Cибирь (pronounced [sibir'], English: Siberia). Selecting this toponym to be precise in terms of onomastics horonym, i.e. the name of a territory, region, district, region, is not accidental. First, made at different times attempts of linguists to describe its derivational structure resulted in only listing derivatives identified by the method of continuous sampling from lexicographic sources, as well as describing their semantic features, including our dissertation study concentrating on this PN [12].
Secondly, the problem of word-formation of toponyms is still not fully investigated and will be relevant for a long time.

Moreover, it is also important to focus on the fact that regional aspect in study of Russian language world picture is of particular importance. Lately, linguists have freely used the term "complex regional linguistic persona", introduced in the early 90's of the last century by I. V. Sentenberg, it has become a full-fledged linguistic concept. This term implies a "generalized, aggregate image of a specific language speaker". What is meant here is interaction of a complex and individual linguistic persona, i.e. "on the one hand, language and speech experience of an aggregate native speaker is extracted from the experience of individual linguistic personae; on the other hand, speech activity of the individual is inconceivable without language experience and traditions of society members. Therefore, belonging of a linguistic persona to a specific language group defines this persona's worldview "[13].

Precisely because regional studies in Linguistics have become quite popular, there originated a new scientific direction - regionalistics or regional studies. As noted by L. G. Vitlinskaya, this "complex discipline of humanities studies the processes and activities of human existence and culture created by him/her in interaction with the surrounding environment within compact geographical space, region" [14]. Nevertheless, Siberia in this context can hardly be called "compact region", especially it once represented the whole state - the Siberian khanate, however, according to geopolitical situation in modern Russia, Siberia is considered as its full-fledged region, stretching its borders in most of the country's territory.

* Corresponding author: anna220381@yandex.ru 
So, "Сибирь" is the regional toponym, horonym. The population of Siberia is an aggregate image of a regional linguistic persona, representatives of the regional language space with a set of regionally marked generally valid background knowledge, which identifies the linguistic persona regarding common historical and cultural space of the region.

Onym Сибирь is not just a name of toponym in the Russian language, it is also the name of a linguocultural concept of Russian language world picture that has been formed for more than four centuries. Let us consider the encyclopedic, though well-known, generally accepted, meaning of this toponym. Siberia (Сибирь) is the territory of Russia, occupying most part of Northern Asia. It is located from the Urals in the west to the Pacific Ocean in the east, and from the shores of the Arctic Ocean in the north to the border with Central Asia (Kazakhstan, China and Mongolia) in the south. The process of numerous toponymic derivatives of this onym throughout Russia seems to be completely natural, since development, involvement of population of vast territory into culture, economic activity, way of life created new object nominations motivated by this toponym: clothes (сибирка, сибирлетка), transport (сибирка), tools (сибиричник), plants (сибирка, сибирёк, сибирячка, сибирник), territories (сибиряк, сибириха), everyday items (сибирька - a swing), money (сибирки) etc.

As noted above, studies on the semantics of PN Сибирь at this stage include only descriptive and aggregate dialectal lexical and phraseological material. So, having sufficient data, collected from numerous dictionaries of Russian dialects and subdialects of various years [12], having conducted morphemic and word-formation analysis of the toponym Сибирь we can present it as a word-formation family of words (WFW). This largest complex unit of word-formation system of language is an "arranged by relations of derivativeness aggregate of words characterized by common root" [15]. Identified toponymic derivatives are united by common roots, not only in terms of the expression plane, but also in terms of the content plane, i.e. the root -сибирexpresses common to all related words element of meaning. Regarding the latter, it should be noted that the question on the meaning of PN, including toponyms, is quite complicated, because its denotation is an abstract concept that includes a complex of linguistic and extralinguistic information. Thus, the WFW of toponym Сибирь comprises derived lexemes, various in terms of content characterizing the present $\mathrm{PN}$ not just as a geographical name, but also as a national and cultural source of background knowledge, features, ideology, connotations, etc. that have spread throughout Russia.

According to analyzed data, the WFW of the toponym "Сибирь" includes 40 highly motivated derivatives, entering among themselves as a component of this WFW into four word-formation paradigms and forming a few word-formation chains. The aggregate of words is strictly arranged, and each derived word takes its own place in WFW, provided by the laws of language and fixed in the standard. The basis of the WFW is a hierarchy principle, the consistent subordination of some units to others, which is reflected in the level-type nature of the representation of word-formation family word.

So, the top of WFW is horonym Cибирь. 19 derivatives are the words of the first level of motivation formed by derivational affixes of the Russian language: Сибирь сибир-як, сибир-ец, си -ск-ий, сибирн-ыій, сибир-ёк, сибир-ушк-а, сибир-ит, сибир-ид, сибир-их-а, сибир-ник, сибир-ия-а, сибирь-ј-ё, сибирь$\kappa-a$, сибир-ях- $а$, сибир-ян-ин, сибир-к-и, сибир-д- $a$, сибир-ич-ник, сибир-щчин-а.

Two derivatives of level I of motivation are formed by the method of addition with suffixation: средн-eсибир-ск-ий, сибир-лет-к- $a$. At level II of motivation three derivatives are formed by this method: сибир-еязв-енн-ый, урал-о-сибир-ск-ий. At level III of derivation one derivative is formed by this method: полу-сибирка.

There are the following word-formation paradigms and word-formation chain:

$$
\begin{aligned}
& \text { 1) сибир-ск-ий } \\
& \text { сибир-к- } a \\
& \text { сибир-оч-к- } а \\
& \text { сибир-к-ов-ьй }
\end{aligned}
$$

полу-сибир-к-а

по-сибир-ск-и

сибир-е-язв-енн-ьій

урал-о-сибир-ск-ий

2) сибир-як

сибир-яч-к- $а$

сибир-яч-ок

сибир-яи-к-ий по-сибир-яи-к-и

сибир-яч-и-ть

сибир-як-а

сибир-яч-ј-ё

3) сибир-еи

сибир-еи-к-ий

по-сибир-ец-к-и

4) сибир-янин

сибир-янк- $а$

сибир-ян-е

5) сибир-ёк

сибирь-к-ов-ый

15 derivatives make up level II and 6 derivatives level III of word-formation derivation.

Identified toponymy-derived formations mainly developed in the Russian language by means of derivational affixes. So, 30 derivatives of lexeme Сибирь are formed by suffixal method, which amounted to $75 \%$ of the total number of derivatives. Word-forming suffixes include the following: -к-, -оч, -ов-, -ушк-, -як-, -ит-, -ид-, -их-, -ник-, -ец-, -ёк-, -ц-, -й-, -яХ-, -янк-, -д, -щин-, -ск-, -н-.

The relations between derivatives and derivating words can be considered in two ways: from a formal and semantic point of view. Based on comparing semantics of $\mathrm{P}_{1}$ (derivating, motivational word) and $\mathrm{P}_{2}$ (derivative) derivational meaning is identified. It is the semantic component that distinguishes $\mathrm{P}_{2}$ from $\mathrm{P}_{1}$. The semantics of derivatives in comparison with the semantics of derivating words includes additional semantic components, i.e. the meaning of femininity (сибиряка) 
or the meaning of an object to carry out an act (сибирка). The same additional semantic components can be identified in the semantics of other derivatives with the same word-formation formants, therefore derivational meaning is of generalized nature and while identifying it, specific lexical meanings of words are not taken into account.

Derivational meaning (DM) is typified ratio of derivating and derivative. It is expressed with the help of the derivational formant. Thus, words сибирка, сибирянка differ from their $\mathrm{P}_{1}$ Сибирь by semantic component "person", they make up different DM, expressed by formant $-\kappa$ - and $-я н \kappa-$.

Derivational meaning is a complex phenomenon, which is determined by:

- meaning of part of speech of a derivating word,

- meaning of derivational formant,

- meaning of part of speech of a derivative word.

Vast majority of derivatives of level I and II of wordformation of the present WFW are represented by nouns, with suffixes acting as derivational formants. Below we present the derivational meaning of the derivatives represented in the language by the given suffixes.

Nouns motivated by nouns according to the model

$\mathrm{S}_{2} \longleftarrow \mathrm{S}_{1}+\mathrm{s}$

DM "male person in his relation to place, settlement"

-як-: сибиряк,

-ник-: сибирник,

-еи-: сибиреи,

-ит-: сибирит,

-ич-ник: сибиричник.

DM "female person in her relation to place, settlement"

$-\kappa-:$ сибирка,

-ян-к-: сибирянка,

-яч-к-: сибирячка,

-очк-: сибирочка,

-ях-: сибиряха,

-ушк-: сибирушка.

DM "animal, characterized by relation to what is termed a motivating word"

-к-: сибирка (horse, sheep, cat, bird),

-яч-к-: сибирячка (breed of sheер),

-як-: сибиряк (cat, bird, horse).

DM "Plant, characterized by relation to what is termed a motivating word"

-к-: сибирка (wheat, rye, buckwheat, potatoes, apple tree, rose family bush, nettle),

-ёк-: сибирёк (plant, chaff flower, kind of grape),

-яч-к-: сибирячка (kind of wheat).

DM "an inanimate object, a tool, a device, characterized by relation to place"

-ит-: сибирит (stone),

-к-: сибирка (transport: sleigh, vessel, boat, van;

clothes: jacket, shirt, skirt, fur coat, ear-flapped hat "ushanka", uniform overcoat; spoon)

-ушк-: сибирушка (poddevka (underclothes), caftan),

-к-: сибирька (winter swing),

-янк-: сибирянка (apron),

-яч-к-: сибирячка (wooden plough),

-очк-: сибирочка (short caftan, coat).
DM "Place characterized by relation to place" -к-: сибирка (forest, road, storage closet, house, pithouse),

-як-: сибиряк (bog, forest),

-д-: сибирда (Siberia),

-к-: сибирияа (river),

-их-: сибирuхa (field, natural landmark, village),

-як-: сибиряк (bog, forest),

-янк-: сибирянка (forest, pasture, place of mowing), -циин-: сибирщина (Siberia).

DM "Object with discrete (abstract) meaning" -к-: сибирка (disease, card game, hard life), -щиин-: сибирщиина (life).

DM "Phenomenon, characterized by relation to place"

-к-: сибирка (north wind),

-як-: сибиряк (snow).

DM "Substance, a material characterized by relation to place"

-к-: сибирка (kind of squirrel fur, green paint),

-як-: сибиряк (rough canvas),

-яч-к-: сибирячка (rough canvas).

DM "Collective concept characterized by relation to

-й-: сибирьё (Siberians), place"

сибирячьё (Siberians).

There are two toponymic derivatives of adjectives of level I of motivation included in the present WFW and formed by the suffixal method according to the model

$\mathrm{S}+\mathrm{s} \longrightarrow \mathrm{Adj}$, they are сибирский and сибирный.

There are three toponymy-derived adjectives of level II of motivation сибирьковый (from сибирёк) and сибиряцикий (from сибиряк), сибирецчкий (from сибиреи).

There are the following DM of derived adjectives and suffixes representing them.

DM "Feature typical of place termed as derivating basis"

-ск-: сибирский (translated: Siberian) (Kamen' (stone) - Ural, virgin soil, place, pinewood, mowing field, field, wood, bog, creek),

-н-: сибирный (house, yard).

DM "Feature of a living being (person, animal), characterized by relation to what is termed as derivating basis"

-ск-: сибирский (Orthodox man, male),

-н-: сибирный (boy, man, prisoner).

DM "Feature of an inanimate object (plant, tool,

device) characterized by relation to what is termed as derivating basis"

-ск-: сибирский (hawthorn, tea, thistle, cornflower, sweet clover, potatoes, apple, pineapple, cedar, flax, salmon, sturgeon, bag, deer, wolf, cat (female cat), stork, polecat, cucumbers, peasant's boots),

-ов-: сибирковый (sledge), сибирьковый (kind of grape, wine).

DM "Feature of an abstract concept, characterized by relation to what is termed as derivating basis"

-ск-: сибирский (life, sickness, space, God, health), -н-: сибирный (life),

-к-: сибирячкий (shchi (cabbage soup)). 
DM "Feature of a natural phenomenon, characterized by relation to what is termed as derivating basis"

-ск-: сибирский ((wind, frost, cold, train (card game), celebration (Day of the conquest of Siberia by Yermak - October 26 according to old style), conversation),

-н-: сибирный (wind)

DM "Feature of substance, characterized by relation to what is termed as derivating basis"

-ск-: сибирский (sodium sulphite, salt).

Prefixal method in formation of toponymic derivatives is not represented.

Derivatives of сибир-д- $a$ and сибир-и- $a$ are formed using unifixes -Д-, -ц-, such parts of a word which cannot be found in any others. They make up 5\% of all derivatives. Let us explain the meaning of the derived words with these unifixes.

Сибирия. In toponymy. The name of the river (Krivoshapov, 2010).

Сибирда. Despisingly. 13. In pre-revolutionary Russia: Siberia. Пусть медведь в Сибирде живёт, кому жись надоела. (Let the bear live in Siberia, who is fed up with life.) Я Сибирдой по горло cыm. (I am fed up with Siberia.) Chitin [12].

Prefixal-suffixal method is used to form toponymyderived adverbs, which are at level II and III of motivation in the present word-formation WFW: noсибир-ски, по-сибиряик-и, по-сибирецк-и. That amounts to $7 \%$ of the total number of derivatives. Their derivational meaning is considered as follows.

DM " In a manner it is peculiar to what is called a motivating basis of a noun"

This DM is expressed by the adverb по-сибир-ски (as in Siberia), formed from the name "Сибирь" (Siberia) with a prefix по- and suffix -ски according to productive and fairly common in the Russian language word-formation model: Adv $\leftarrow S+$ pr (по-) + s (-ски).

DM " In a manner it is peculiar to what is called a motivating basis of an adjective"

Two other adjectives, formed by prefix по- and suffix -и, have such DM: по-сибиряик-и (as Siberian man), nо-сибирецк- $u$ (as Siberian resident). They represent the following word-formation model: Adv

$$
\leftarrow \operatorname{Adj}+\operatorname{pr}(\text { по-) + s (-и). }
$$

The only verb in the analyzed word-formation family word сибирячить is formed by suffix method from the noun сибиряк (a Siberian). Let us consider its DM.

DM "to perform an action named by a noun in a derivating basis" does.

-и-: сибир-яч-и(ть), i.e. to do and live as a Siberian

Word-formation model in this example is as follows: $\mathrm{V} \leftarrow \mathrm{S}+\mathrm{s}(-\mathrm{-}-)$.

Thus, word-formative family word with toponym Сибирь (Siberia) as a top, according to our calculations, consists of 40 derivatives, located at three levels of word-formative motivation; in terms of belonging to a specific part of speech they are predominantly nouns (27), adjectives (9), adverbs (3) verb (1).

There are 21derivatives at level I, 14 - at level II, 5 at level III.
Quantitative analysis of methods of toponymyderived word-formation of WFW of proper name Сибирь showed that $80 \%$ of the derivatives are formed by suffixal method, $7 \%$ - prefixal-suffixal, $13 \%$ - with the combining with suffixation.

In addition to the morphological word-formation (affixation), there are also non-morphological methods in this WFW. This is mixed combining, which is partially touched on above: combining bases with suffixation, as well as substantivation (one $\mathrm{P}_{2}$ ) and univerbation (one $\mathrm{P}_{2}$ ).

The following derivatives сибирлетка, полусибирка, сибиреязвенныци, среднесибирский, урало-сибирский are formed by combining affixation, which is $13 \%$ of the total number of toponymy-derived new formations.

Noun сибирнылй is substantivized, it has two meanings in this quality: 1) prisoner, 2) a scoundrel, rascal. This substantive is derived from the adjective сибирный (Siberian prisoner).

Univerbation (uni - 'one' + verbum 'word') it is a method of word-formation, when on the basis of collocations of an adjective and a noun with the suffix $\mathrm{k}$ - (-ик-) a new word is formed. Not the whole phrase is used as derivating base, but only its first part - a reduced base of the adjective. In this case we consider word сибирка in its various meanings formed from the respective phrases:

сибирка (winter-proof apple tree) $\longleftarrow$ сибирежая яөлөня + s (-к-) (Siberian apple tree)

сибирка (women's outerwear) $\leftarrow$ сибирежая куртка + s (-к-) (jacket), сибирка (disease) $\leftarrow$ сибирекая язда $+\mathrm{s}(-\mathrm{\kappa}-)$ (anthrax).

Analyzing the process of word-formation from onym "Сибирь", it is also important to note that it involves some morphonological phenomena inherent to the Russian language. In the theory of linguistic wordformation such phenomena involve changes in the composition of derivating base or derivational means, which occur during the formation of the derivative to eliminate unwanted combinations of sounds. Morphonological phenomena include alternation of vowels and consonants, shift of stress, reducing the derivating base, the overlaying of morphemes, interfixation. It results in adjustment of the derivating base and word-formative affix. Morphonological phenomena do not affect semantic relations between derivating and derivative words

The alternation of sounds. Phonemes at the end of derivating base, adjust to the initial phonemes of wordformative affixes. So, in pairs $\mathrm{P}_{1}$ and $\mathrm{P}_{2}$, we can observe the alternation of the phonemes: Сибирь $\rightarrow$ сибирка [p, // p], сибиряк $\rightarrow$ сибирячок [к// ч']. So, alternation of the phonemes is represented by alternation of hard and soft consonants and traditional characters.

Shift of stress. Mobility and various positions of Russian stress gives the possibility to use it as wordformation means. In some derivatives there has been a change in the place of stress: Сибирь $\rightarrow$ cибири'

сибиря'к $\rightarrow$ сибирячьё.

Reducing derivating base. In the formation of words in the intersection of derivating base and word- 
formative affix sound combinations occur, which are not characteristic for the modern Russian language. This causes the simplifying of the end of derivating base, it is subject to reducing. Reducing derivating base in the present WFW can be found in the derivative: сибиряне сибирянин..

Overlay (interference, applique) of morphs is morphonologic phenomenon involving connection of identical segments of adjacent morphs.

For example, Сибирянин $+\mathrm{s}(-\kappa-) \rightarrow$ сибирянка (сибирян(ин)ка) огсибирский $+\mathrm{s}\left(-\mathrm{\kappa}^{-}\right) \rightarrow$ сибирка (сибир(ск)ка).

The word сибирка is the most common toponymic derivative of this WFW in the regional world picture of native speakers of the Russian language. According to our data, it has 34 meanings, representing the perception of Siberia as a versatile, multifaceted space, predetermining the emergence of so many meanings [12]. Below there are the meanings of the lexeme "сибирка" recorded in dictionaries [12].

1. Ancient overclothes in the form of a short caftan to the waist, puckered up and with a stand-up collar. Однажды в магазин Кроликова вошел одетый в сибирку рыжсий мещанин. (translation: Once a redhead petty bourgeois entered the Krolikov's shop; he was dressed in sibirka). N. Uspensky. Bookstore.

Figurative meaning Colloquial About the person dressed in such clothes. Оперетта пришлась как нельзя более кстати и для аристократического зрителя, франиузской труппь Михайловского театра и для «сибирок», завоевавших партер Александрийского театра. Operetta was just at the right time both for aristocratic audience, French troupe of the Mikhailovsky theatre and for "sibirkas", who won the orchestra seats of the Alexandrinsky theater. Yankovsky. Operetta.

2. Obsolete, colloquial. Prison. At that time the volost was headed by starshina there were the officers, commanders of sotnia, 10-men units, a Cossack sergeant was a judge, they put people in prison (sibirka). Irkut., Kiren.

3. Colloquial Сибирская язва. (Splenic fever). Отойдите, товарищи, - сказал [ветеринар] веско, есть опасение, что это сибирка. (translation: Stand back, comrades, ' said [the vet] convincingly, there is concern that this is sibirka (anthrax)). Корову со всеми предосторожностями отволокли за село, зарыли. (translation: Cow with due safety precaution was brought out of the village and buried). A. N. Tolstoy. Mother and daughter.

4. Green paint representing water carbonic oxide of copper.

5. Kind of winter-resistant apple tree and fruit of it. Пыиные яблони-сибирки уже нынешним, летом создадут непролазную ограду. (translation: Lush sibirka apple trees as early as this summer will create an impassable fence). A. Kozhevnikov. Living water.

Kind of rose family bush. [Сергей] видел выздоровевиих ревматиков, пивших настой сибирки. (translation: [Sergey] saw the cured rheumatics who drank the tisane of sibirka). Serafimovich. Two nights.
7. Obsolete. Type of the card game. У меня будуm брат Петя и Н. И. Давыдов, поиграем в сибирку, -я весь пост добивался этого удовольствия. (translation: My brother Peter and N.I. Davydov will come to my place, we 'll play sibirka; entire fasting, I sought this fun.) A. Ostrovsky. Letter to N. P. Musil, March 24, 1875.

8. Prison cell in the police station, at the volost (district) administration: cell with fleas, icebox.

9. Ship from the Kama river, usually with iron.

10. Paper monetary unit.

11. Kind of squirrel fur (Siberian squirrel).

12. A Siberian girl or woman. Сибирки девки бравы. (translation: Sibirkas girls are smart). Сибирка хоть куда, и работать может, и сполюбит, так крепко. (translation: Sibirka is a humdinger, she is able to work, and when she loves, she loves dearly). Buryat, Barguzin.

13. In pre-revolutionary Russia: a) Vladimirskiy Trakt, b) Siberian railway. На сибирке работал разный люд. Когда сибирка была пущена, то жись здеся изменилась. (translation: At sibirka different people were working. When sibirka was launched, the life here changed). Buryat., Kabansk.

14. Obsolete. Forced labour camp На сибирке тута многие побывали. (translation: Here at sibirka many people have been). Кто на сибирке побывал, тот горя похлебал. (translation: They who in sibirka (forced labor сатр) were experienced the grief). Десять лет на сибирке кандаль таскал. (translation: During ten years at sibirka (forced labor camp) he was wearing shackles). Buryat, Ulan-Uden.

15. Ragged clothes of a prisoner-convict. По сибирке видно, кто такой. (translation: One can understand who the man is according to his sibirka (clothes)). Chitin.

16. A large piece of boiled meat. Вот эту сибирку съем, малость насытюсь. (translation:When I eat this sibirka (piece of meat), then I'll be sated a little bit). Chitin.

17. Pit-house, a common housing of mine workers. $B$ сибирке родился, в сибирке вырос. (translation: In sibirka (pit-house) he was born, in sibirka (pit-house) he grew up.) Да разве в сибирке мог ребёнок здоровылм pacmu. (translation: Could a child grow healthy in sibirka (pit-house).) В сибирке всегда духота была, темень. (translation: In sibirka (pit-house) there was stuffiness and darkness). Так в сибирке и мытарились. (translation: So, they suffered afflictions in sibirka (pithouse)). Buryat.

18. Sledge, not iron-bound. От Урала до Нерчинска на сибирке тащился, на ней всю скорбь везли. (translation: From the Urals to Nerchinsk on sibirka (sledge, not iron bound) he crawled, on it all sorrow was driven.) Пару в сибирку не запрягали, на одной кляче ташились. (translation: Two horses were not hitched into sibirka (sledge), one decrepit horse dragged it). Buryat.

19. Low-growing hardy horse with long hair. Hawux дедов сибирка выручала. (translation: Our forefathers were helped out by sibirka (horse)). Buryat, Tunkin.

20. Kind of strawberry named Victoria, sweet and early ripening. Первая ягода у нас в поселке сибирка. (translation: The best berry in our settlement is 
sibirka (strawberry)). Krasnoyar., Yermakov.

21. Nettle. Косить сибирку. (translation: To mow sibirka (nettle)). Krasnoyar., Krasnotur.

22. Cold-resistant variety of wheat with a long awn, a fine grain, having long been cultivated in Siberia. Сибирка не родилась, земля плоха была. (translation: Sibirka (wheat) didn't grow, the ground was bad). Irkut.

23. A disease of cattle. Сибирка, кровь внутри заражачияа, мьшики и колики у лошадей и коров, вздутие делащиа. (translation: Anthrax, blood inside is infected, horses and cows have colicky pain and flatulence.) Khakas.

24. Long sheepskin coat with a woolen cloth top. Kashin. Tver., 1897. A поддевка-то на вате, A сибирка на меху (folk rhyme).(translation: And poddevka (underclothes) is with the cotton wool, And sibrka is with the fur). Tver.

25. Jacket. Urzhum. Vyat., 1882. || Quilted sleeveless jacket. Сибирки шили на ваты. (translation: Sibirka jackets were sewn with cotton wool). Metin. Novg., 1948.

26. Fur hat with long ears. Arch., 1901-1905. Шапка сибирка, посеред дырка. (translation: A sibirka hat, with a hole in the middle). Porech. Smol.

27. Kind of rye. Soligalich. Kostrom., 1990.

28. Kind of buckwheat. Греча (Buckwheat): сибирка и русская (sibirka and Russian) Nizhegor.

29. Kind of potato, kind of forage. Poshekh. Yarosl., 1990.

30. Vegetable, sweeter than turnip. Yarosl., Melnichenko, 1961.

31. Large wooden spoon with a painting. Semyon. Gorky, 1879. Сибирка была гладкой и писаной. (translation: The sibirka (spoon) was smooth and decorated). Gorky.

32. Mn. Paper monetary notes issued by Kolchak during the civil war. Унесешь в лавку куль сибирок и возьмешь фунт соли. (translation: Yои can bring a bag of sibirkas (paper monetary notes) to a shop and take a pound of salt). Вот какая иена была сибиркам. (translation: That's what the price was to the money). Transbaikalia, 1980.

33. Any abscess, purulent inflammation of the skin with high fever; carbuncle. Kozl. Tambov, 1897.

34. North wind. Additional, 1929

«Сибирка» can be found in 1, 2, 3, 4, 8 meanings in the dictionary by V. I. Dal and in the "Dictionary of the Russian language in 4 volumes" (1961). In the "Dictionary of modern Russian literary language" (1962), the lexeme is marked in 1, 2, 3, 4, 5, 6, 7 meanings. Other meanings of this lexeme can be found only in the dictionary of Russian folk dialects. In the works by S. I. Ozhegov and D. N. Ushakov, this definition is not represented.

Apart from grammatical word-formation of onym "Сибирь", discussed in detail above, we believe it is important to consider the process of semantic wordformation as well. What is meant here is so called appellativation, or de-onymation, transferring an onym into appellative without affixation. Having comprehensively studied toponym Сибирь, we found out that it is involved in the process of appellativation, or more correctly in our case, detoponymization, transferring a meaning of the proper name to the common one. It can be revealed in the following meanings:

1) сибирь - wedding celebration drinks, i.e. wine, vodka that the groom offered in his yard. Пойдем сибирь пить. (translation: Let's go to drink sibir.)

2) сибирь - unbearably hard life, anguish. $K$ братиу я в то время не ходил, ежели случится, то очень редко: по той причине, что окромя уныния завели они другую сибирь - гитару... (translation: At the time I did not go to my brother, if happened, it was very rare: for the reason that besides from melancholy they acquired another anguish thing - guitar...)

3) сибири- Siberian old -residents. В Мыиляяке больше расейски живут, а сибирей мало. (translation: In Myshlyanka there are more Russians and there are few Siberian old residents) (Krivoshchapova, 2010).

4) сибирь - a hopeless situation. Bcë! (translation: That's that! It's over!) Дело - сибирь! (translation: The matter or situation is hopeless'!)

These conversions demonstrate such types of detoponymization as place (geographical object) object, place - person, place - abstract thing.

The process of transtoponymization is also considered to be of interest, it implies transition of the toponym of one kind into another. Thus, horonym "Сибирь" (Sibir) is used by speakers of regional language world picture to refer to the river of Sibir, field Sibir, the area Sibir outside Chulym district of Novosibirsk region, the Sibir bog, pasture, the village of Sibir.

Judging by the diversity of human ideas about сибирка as an integral part of the concept of Сибирь, we can conclude that it evolved and developed in the world picture of native speakers as a distant, remote place, a remote piece of land, extensive unfavorable for agriculture space with uncomfortable dwellings, where simple, often uneducated people, including convicts, prisoners tried to arrange their life. This is cold territory where cold-resistant varieties of plants grow. It involves tough conditions for the existence and severe and joyless life, in which it is necessary to eat substantially and a lot. It is remarkably great Siberian health and diseases.

Word-formation as a branch of linguistics developed rapidly in the last century and is developing today. However, when analyzing a word-formation system, beyond the studies there are still many aspects of the system organization of this level and its interaction with other linguistic levels. Derivatives differ from nonderivative by the fact that they have a special derivational meaning. Toponymy-derived formations (toponymic derivatives), actively used by native speakers, represent specific linguistic units and constitute a rich linguistic source, revealing little-known aspects of the language at all levels. Toponymic wordformation family word as an element of the language world picture illustrates the generally accepted principle of anthropological paradigm of "Language - culture ethnos". Being a core of toponymic space, lexical complex of geographical names constructs the semantic 
and word-formation field, revealing the formation and functioning of this space in the language.

\section{References}

1. E. O. Borisov, Yu. A. Krivoshchapova, B. S. Kuchko, N. A. Sinitsa, Problems of onomastics 2(15), 174199 (2013)

2. Yu A. Krivoshchapova, A. A. Makarova, Questions of onomastics 2 (9), 106 to 122 (2010)

3. R. G. Zhamsaranova, Tomsk journal of linguistics and anthropology, TJLA 1 (7), 32-42 (2015)

4. L. I. Gorbunova, Siberian journal of philology 1, 208220 (2017)

5. N. V. Bubnova, Siberian journal of Philology 2, 197212 (2017)

6. I. A. Dambuyev, Siberian journal of philology 1, 208212 (2016)

7. I. A. Dambuyev, Language and Culture 38, 23-39 (2017)

8. A. S. Shcherbak, Issues of Cognitive Linguistics 4, 110-113 (2016)

9. S. A. Pitina, Issues of cognitive linguistics 1, 53-57 (2017)

10. A. M. Litovkina, Vestnik of ISLU 3 (11), 33-39 (2010)

11. D. Gillespie, S. K. Gural, A. A. Kim-Maloney, Language and culture 40, 8-19 (2017)

12. A. M. Litovkina, "Siberia" Concept and its evolution in Russian language world picture: from the "Siberian Chronicles" to publicism by V.G. Rasputin: Dis. ... Cand. PhD. Sciences (M., 2008)

13. I. V. Sentenberg, Linguistic persona: problems of meaning and sense, 14-24 (1994)

14. L. G. Vitlinskaya, R. A. Tkacheva, N. D. Mikhailova, Issues of Regional Linguistics, 171-174 (2013)

15. A. N. Tikhonov, The Modern Russian language. Morphemics. Word formation. Morphology (Tsitadel -Trade, M., 2002) 